\title{
EVALUATING THE PHYSICOCHEMICAL AND BACTERIOLOGICAL CHARACTERISTICS OF ALIGODON RIVER AS SOURCE OF POTABLE WATER FOR NEW CLAVERIA WATER SYSTEM
}

\author{
Alexander L Ido ${ }^{1}$ \\ ${ }^{I}$ Assistant Professor, Institute of Engineering and Technology, MOSCAT, Philippines
}

\begin{abstract}
To champion the need of providing quality water to the community, a study on characteristics of the water source is important and of primary consideration. This study aims to determine the physicochemical and bacteriological features of Aligodon River, a drinking water source of new Claveria water system, regarding temperature, turbidity, total dissolved solids (TDS), dissolved oxygen (DO), pH, phosphates, nitrates, biochemical oxygen demand (BOD) and coliform level. The result revealed that TDS, $D O, p H, B O D$ all passed the standards of Philippine National Standards for Drinking Water while turbidity and total coliform all failed in any season of the year. Based on the permissible standards set by DAO 34,TDS, DO, and pH all passed the Class AA classification. The coliform level is present in river water but unquantified which necessitates treatment to attain the desired quality of the water free of pathogen.
\end{abstract}

Keywords: Water Treatment, Drinking Water Source, Water Quality, Physicochemical Characteristics

\section{INTRODUCTION}

Water is considered as the lifeblood of the earth. It is a vital substance in building tissues of flora and fauna at all stages of growth and development. Life on earth definitely would not exist without water. For human beings, health and survival are greatly dependent on the supply of clean water. The combination of safe drinking water and adequate sanitation reduces humans' morbidity and mortality rates [1]. Because of unsafe and unreliable water, high incidence of water-borne diseases is experienced in the Philippines [2]. The availability of clean and quality water is, indeed, a strong yardstick of the life existence and success of any community.

The hinterland communities of Claveria, Philippines, namely; Lanise, Luna, Tamboboan, Ane-i, and Patrocinio have experienced scarcity and poor quality of water supply. They have no adequate drinking water supply as they are located on the plateau where most of its water drains to the lower ground. Situational analysis of Claveria in 2009 [3], showed that only $23.84 \%$ of its households have access to pipe waterworks level 2 (communal) while the other 58.62\% get water from the spring and river. The remaining $7.75 \%$ and $9.79 \%$ have been getting water from an open shallow dug well and artesian well, respectively. Most, if not all, of these sources do not have analysis to manifest its safety and potability. The situational analysis evidently showed that hinterland places of Claveria have experienced scarcity of water supply. In summer time, people have to travel to neighboring community like Mat-i to fetch water. Mat-i is another community of Claveria that has a number of potentially potable water sources like springs and rivers. One of the rivers of Mat-i that is looked as good source of drinking water is the Aligodon River.
In answering the pressing demand for potable water of the said communities, the Local Government Unit (LGU) of Claveria prioritizes new water system project by tapping the Aligodon River of Mat-i. This study investigates the physicochemical and bacteriological properties of Aligodon River during wet and dry seasons. This is important because the treatments needed before the water will be delivered to the concessionaires are dependent on its properties. It is of prime consideration and responsibility of water providers to deliver safe and clean water that pass the minimum standard set by the Philippine National Standard for Drinking Water. Hence, this study is conducted.

\section{MATERIALS AND METHODS}

\subsection{Establishment of Sampling Stations}

Two (2) sampling stations were established in the study area. The first station (lower station) was about 10 meters above the diversion site of the water system. The vegetations along the riverbank of 20 meters radius are few banana and chayote plants, after which are forest areas in hilly lands on both sides of the river. The second station (upper station) was approximately 250 meters from the first station. This second station was the headwater right after an unnamed stream tributary that met the Aligodon River main channel.

\subsection{Collection of Data}

The water samples were collected through grab sampling technique. Samples were collected separately in each season with one sample at each station. The sampling started at 10:00 in the morning for the aquatic environment to be contacted with the ambient condition like solar radiation. 
Water sampling was done first at the lower station to make sure that no disturbance of water at the upper station.

In grab sampling, a single sample was taken over a very short period of not more than 15 minutes. In this technique, the container in getting the sample was submerged at an average depth of the water bodies allowing it to full within a couple of minutes. It is a requirement that the quantity of water taken was sufficient enough for the testing of all the physical and chemical analyses.

\subsection{Treatment of the Study}

The study used two treatments. The first treatment $\left(\mathrm{T}_{1}\right)$ was the dry season while the second treatment $\left(\mathrm{T}_{2}\right)$ was the wet season.

Each of the treatment got a sample in the two (2) established stations during one sampling period. During one season sampling, there were two (2) samples taken at the upper station and another two (2) samples at the lower station.

Table 1. Treatment of the Study

\begin{tabular}{|c|c|c|c|c|}
\hline \multirow[t]{2}{*}{$\begin{array}{c}\text { Treatment } \\
\text { (Season) }\end{array}$} & \multicolumn{4}{|c|}{$\begin{array}{c}\text { Replication } \\
\text { (Sampling Period) }\end{array}$} \\
\hline & \multicolumn{2}{|c|}{$\begin{array}{c}\underline{\mathrm{R}}_{1} \\
\text { Lower Station }\end{array}$} & \multicolumn{2}{|c|}{$\begin{array}{c}\underline{\mathrm{R}}_{2} \\
\text { Upper Station }\end{array}$} \\
\hline $\mathrm{T}_{1}$ (dry season) & $\mathrm{T}_{1} \mathrm{R}_{11}$ & $\mathrm{~T}_{1} \mathrm{R}_{12}$ & $\mathrm{~T}_{1} \mathrm{R}_{21}$ & $\mathrm{~T}_{1} \mathrm{R}_{22}$ \\
\hline $\mathrm{T}_{2}$ (wet season) & $\mathrm{T}_{2} \mathrm{R}_{11}$ & $\mathrm{~T}_{2} \mathrm{R}_{12}$ & $\mathrm{~T}_{2} \mathrm{R}_{21}$ & $\mathrm{~T}_{2} \mathrm{R}_{22}$ \\
\hline
\end{tabular}

\subsection{Testing Procedure}

The temperature and the flow rate of the water were tested on-site. Glass thermometer was used in determining the temperature of water. The float method adopted by Waterwatch Philippines [5] was employed in the determination of the water flow of the river water.

In every station at one sampling period, a 4-liter container was filled with river water intended for the analyses of turbidity, TDS, pH, nitrate, phosphate, and BOD. Also, a 500-ml bottle was filled with river water designed for the analysis of the total coliform. These filled containers were immediately placed in a cold iced bucket. After the samples had been taken at both stations, these were immediately transported to the Analytical Laboratory Services Center of the Mindanao University of Science and Technology (MUST), in Cagayan de Oro City for analysis.

The result of the testing was compared to the standards of PNSDW [6] and DAO 34 [7]. Concerning nitrates, the result in the laboratory is expressed as total nitrates $\left(\mathrm{NO}_{3}\right)$. The DAO 34 showed a permissible value in nitrate-nitrogen $\left(\mathrm{NO}_{3}-\mathrm{N}\right)$ which is the amount of nitrogen in the nitrate form. Hence, the laboratory result was converted with this equality: $10 \mathrm{mg} / \mathrm{L}$ of $\mathrm{NO}_{3}-\mathrm{N}=44.3 \mathrm{mg} / \mathrm{L}$ of $\mathrm{NO} 3-$ [8]. Similarly, the permissible standard of DAO 34 for phosphate is expressed as phosphorous. Thus, the conversion of phosphate to phosphorous adopted by
Environment Australia [9] was employed: the phosphate $\left(\mathrm{PO}_{4}\right)$ content is divided by 3 , and the quotient is the conversion value in Phosphorus.

\subsection{Statistical Analysis}

The data gathered in the study were subjected to descriptive statistics in the determination of the mean of the studied properties. The F-test was used in the determination of the equality of variance of the characteristic tested. The t-test was used at $5 \%$ level of significance in the determination of whether or not there is a significant difference in the characteristics of river water taken during wet and dry seasons, and at the lower and the upper stations.

The mean value of the characteristics tested was compared to PNSDW. Moreover, the mean value was also compared with the Class AA and Class A waters set by DAO 34. The value of the parameter that met the permissible standard for drinking water means that such parameter passes the requirement set by PNSDW and Class AA and Class a of DAO 34.

\section{RESULTS AND DISCUSSION}

\subsection{Physicochemical Characteristics of Aligodon River Water}

Table 2 shows the physicochemical characteristics of Aligodon River. The result illustrates that the mean temperature of the river water is $21.06{ }^{\circ} \mathrm{C}$. In term of its clarity, measured through turbidity, it was found out that the mean value was 54.75 NTU. The TDS revealed a mean value of $58.38 \mathrm{mg} / \mathrm{L}$ and its DO disclosed a mean value of $8.03 \mathrm{mg} / \mathrm{L}$. It was also found out that the river water has a mean $\mathrm{pH}$ value of 6.83 . Further, the result discloses a mean value of $0.52 \mathrm{mg} / \mathrm{L}$ and $8.46 \mathrm{mg} / \mathrm{L}$ of phosphates and nitrates, respectively. The BOD mean value was found at $0.92 \mathrm{mg} / \mathrm{L}$.

Table 2. Physicochemical Characteristics of Aligodon River Water

\begin{tabular}{|c|c|c|c|c|c|}
\hline \multirow{2}{*}{ Parameter } & \multicolumn{2}{|c|}{ Dry Season } & \multicolumn{2}{|c|}{ Wet Season } & \multirow[t]{2}{*}{ Mean } \\
\hline & Upper & Lower & Upper & Lower & \\
\hline Temperature, ${ }^{\circ} \mathrm{C}$ & 2.00 & 23.00 & 19.25 & 20.00 & 21.06 \\
\hline Turbidity, NTU & 30.99 & 50.00 & 0.00 & 88.00 & 54.75 \\
\hline $\begin{array}{l}\text { Total Dissolved } \\
\text { Solids, mg/L }\end{array}$ & 32.00 & 32.5 & 6.75 & 82.25 & 58.38 \\
\hline $\begin{array}{l}\text { Dissolved Oxygen, } \\
\mathrm{mg} / \mathrm{L}\end{array}$ & 7.43 & 7.67 & 8.56 & 8.48 & 8.03 \\
\hline $\mathrm{pH}$ & 6.84 & 7.01 & 6.71 & 6.75 & 6.83 \\
\hline Phosphates, mg/L & 0.023 & .005 & 0.67 & 1.40 & 0.52 \\
\hline Nitrates, mg/L & 6.30 & 6.20 & 10.18 & 11.16 & 8.46 \\
\hline $\begin{array}{l}\text { Biochemical } \\
\text { Oxygen Demand } \\
\text { (BOD), mg/L }\end{array}$ & 1.14 & 1.35 & 1.2 & nil & 0.92 \\
\hline
\end{tabular}




\subsection{Coliform Level of Aligodon River Water}

Table 3 shows the coliform level of the river water observed during wet and dry seasons. It is not presented using its mean value because of the TNTC (Too Numerous to Count) readings. The TNTC reading means that the number of colonies of coliform is too crowded and dense that it cannot be counted anymore. Based on the result, this TNTC (Too Numerous to Count) readings were observed in both seasons, and it is detected twice during the wet season. The result reveals that coliform level during the wet season is quite varied, and its magnitude is high.

Table 3. Total Coliform Level of Aligodon River Water during Wet and Dry Seasons

\begin{tabular}{lcc}
\hline \multirow{2}{*}{ Parameter } & \multicolumn{2}{c}{ Coliform Level } \\
\cline { 2 - 3 } & Wet season & Dry season \\
\hline Coliform, & 1,4, TNTC, and & $219,189,99$ and \\
colonies per $100 \mathrm{ml}$ & TNTC & TNTC
\end{tabular}
* TNTC - an abbreviation for Too Numerous to Count which means that the number
of colonies is too crowded and dense that it cannot be counted anymore

The result implied that total coliform is present in the river in both seasons. The result also depicts TNTC reading of both seasons of which wet season recorded two (2) TNTC readings. In comparison, dry season's coliform level is consistently high level while coliform level during the rainy season is variable.

The result reveals that coliform level is numerous during the dry season with recorded value of 219,189, 99 colonies $/ 100 \mathrm{~mL}$ and TNTC. This finding suggests that total coliform bacteria regardless of its sources intruded and accumulated in the river during the dry season. On the other hand, the total coliform level during the wet season is extremely variable with two extremely low values and two TNTC values. The result shows that total coliform is present in the river in both seasons but this does not necessarily indicate unsafe water [6]. Total coliform is commonly found in soil, on vegetation, surface water, decaying matter (vegetative) and fecal matters of animals and humans [11]. Tchobanoglous [12] also pointed out that the presence of coliform does not always mean contamination with human wastes. The Escherichia coli presence is the best indicator of the contamination of fecal matter and the possible presence of pathogens.

Based on the land use of the watershed and the actual inspection of the site, it is rarely possible that river water will be contaminated with fecal matters from human and domesticated animals because the watershed is very far from the residences. Further, it is surrounded by forest whereby the north portion is dominated by primary forest while secondary forest dominated the southern part. No human settlement existed right then in the area. However, further study on the analysis of $E$. coli may clarify and strengthen the result of this study. On the other point, for assurance, disinfection process is a necessity before the river water will be delivered to the community for domestic use.
Table 4. Coliform Level of Aligodon River at the Upper and the Lower Stations

\begin{tabular}{lcc}
\hline \multirow{2}{*}{ Parameter } & \multicolumn{2}{c}{ Coliform Level of Samples } \\
\cline { 2 - 3 } & Upper Station & Lower Station \\
\hline $\begin{array}{l}\text { Coliform, } \\
\text { colonies } / 100 \mathrm{~mL}\end{array}$ & $1,4,219$, and & 99, TNTC, TNTC, \\
& 189 & and TNTC
\end{tabular}

* TNTC - an abbreviation for Too Numerous to Count which means that the number of colonies is too crowded and dense that it cannot be counted anymore

Table 4 presents the coliform level of Aligodon River at the upper and lower stations. The result reveals that coliform level is numerous in lower station compared to the upper station. The lower station recorded coliform levels of 99 colonies per $100 \mathrm{ml}$ and three TNTC readings. This finding suggests that coliform bacteria between the two sampling stations intruded into the waterway. On the other hand, upper station coliform level readings are 1, 4, 219, and 189 colonies /100 mL.

The result implies that coliform bacteria are present in the river water. Though analysis of $E$. coli is the confirmatory indicator of fecal contamination, however, appropriate treatment is needed to assure water quality before it will be served to the community.

\subsection{Aligodon River Water Characteristics and the} Philippines National Standards for Drinking Water

Table 5 disclosed the mean values of the physicochemical characteristics of Aligodon River and the permissible values of the Philippine National Standards for Drinking Water (PNSDW). Based on the table, both turbidity values of Aligodon River water during wet and dry seasons of 69 NTU and 40.50 NTU, respectively exceeds the permissible standards of 5 NTU set by the PNSDW. This result suggests that the river water needs to be treated because materials suspended in water may serve as the hiding place of the microorganisms during disinfection.

On TDS, PNSDW set a $500 \mathrm{mg} / \mathrm{L}$ permissible standard to consider a water source potable. In Aligodon River water, the result of TDS analysis printed out $86.00 \mathrm{mg} / \mathrm{L}$ during the wet season and $32.25 \mathrm{mg} / \mathrm{L}$ during the dry season. These TDS values pass the permissible PNSDW standard. This finding means that the concentration of dissolved solids present in the water is tolerable.

The amount of DO of Aligodon River water passes the permissible standard set by the PNSDW both during the wet and dry season. The DO values of $8.52 \mathrm{mg} / \mathrm{L}$ and $7.55 \mathrm{mg} / \mathrm{L}$ during the wet and dry season respectively are above the PNSDW permissible minimum requirement of $2-5 \mathrm{mg} / \mathrm{L}$. DO has no direct effect on public health, but drinking water with high DO tastes appetizing. This result implies that the river water of Aligodon possesses positive quality due to high DO content that will make it more pleasant and appetizing to people when to use in their respective household. 
Table 5. Comparison of the Physicochemical Characteristics of Aligodon River and the PNSDW Permissible Standards

\begin{tabular}{|c|c|c|c|c|}
\hline \multirow[b]{2}{*}{ Parameter } & \multirow{2}{*}{$\begin{array}{l}\text { PNSDW Standard } \\
\text { Value }\end{array}$} & \multicolumn{2}{|c|}{ Mean Value } & \multirow[b]{2}{*}{ Remarks } \\
\hline & & $\begin{array}{c}\text { Wet } \\
\text { Season }\end{array}$ & $\begin{array}{c}\text { Dry } \\
\text { Season }\end{array}$ & \\
\hline Turbidity, NTU & 5 & 69.00 & 40.50 & all Fail \\
\hline TDS, mg/L & 500 & 86.00 & 32.25 & all Pass \\
\hline DO, mg/L & $2-5$ & 8.52 & 7.55 & all Pass \\
\hline $\mathrm{pH}$ & $6.5-8.5$ & 6.73 & 6.93 & all Pass \\
\hline Nitrates, mg/L & 50 & 10.67 & 6.25 & all Pass \\
\hline BOD, mg/L & $1-15$ & $0.60^{*}$ & 1.24 & all Pass \\
\hline Total Coliform, MPN/100 mL & 0 & $* *$ & $* *$ & all Fail \\
\hline Temperature, ${ }^{\circ} \mathrm{C}$ & - & 19.50 & 22.63 & - \\
\hline Phosphates, mg/L & - & 1.03 & 0.01 & - \\
\hline
\end{tabular}

* with two (2) nil values equated to zero. The nil value means extremely low concentration and not detectable by existing equipment

** with TNTC values. The TNTC value means Too Numerous to Count that the water microorganisms is too crowded that cannot be counted anymore

For $\mathrm{pH}$ level, the result showed that Aligodon River has a $\mathrm{pH}$ of 6.73 during the wet season and 6.93 during the dry season. These results are within the standard range of PNSDW of 6.5-8.5. This finding means that the $\mathrm{pH}$ of the Aligodon River passes the requirement of a good water source for drinking.

Based on the result, nitrates content of the river water of $10.67 \mathrm{mg} / \mathrm{L}$ during the wet season and $6.25 \mathrm{mg} / \mathrm{L}$ during the dry season are both acceptable based on the permissible 50 $\mathrm{mg} / \mathrm{L}$ set by the PNSDW. This outcome means that the amount of nitrates that are dissolved in water is tolerable. The result implied that the potential sources of nitrates are the decaying organic materials and wastes of wild animals which do not considerably pollute the river.

As seen in Table 5, there is no standard value set by PNSDW for the temperature of drinking water. Based on the result, the temperature of the river water during wet and dry seasons which are $19.50{ }^{\circ} \mathrm{C}$ and $22.63{ }^{\circ} \mathrm{C}$; respectively, implies higher acceptability to would-be concessionaires because it is cold. According to Nathanson [13], the temperature in public water supplies is significant for the fact that cold drinking water is favored by most people. Hence, cold water satisfies the need of a person to refresh oneself.

Like temperature, there is no standard set for phosphates. Nevertheless, the phosphates contents observed during both seasons are too little to affect the water quality of the river.

The permissible BOD of the river water as set by the PNSDW is $1-15 \mathrm{mg} / \mathrm{L}$. Based on the result, the BOD during wet and dry seasons are within the standard permissible range. The BOD during the wet season is $0.60 \mathrm{mg} / \mathrm{L}$ while $1.24 \mathrm{mg} / \mathrm{L}$ at the dry season. This finding is implying good quality water since it is way below the standard permissible range of the PNSDW.
Regarding coliform level, the mean value could not be presented due to the TNTC values both during wet and dry seasons. The TNTC value could not be quantified because the laboratory analysis fails to count them due to a full number of coliform organisms found in the sample. The result indicates that there is contamination of coliform to the river water. The river water may have pathogen-carrying microorganisms. Thereby, the study on the analysis of $E$. coli is recommended to confirm the presence of the pathogen. Further, appropriate treatment is very necessary before the water will be brought to the end pipe for consumption.

\subsection{Aligodon River Water Characteristics and the DAO 34 of 1990}

Based on the TDS content observed during wet and dry seasons, the result revealed that the $86.00 \mathrm{mg} / \mathrm{L}$ TDS content during wet season, and $32.25 \mathrm{mg} / \mathrm{L}$ during dry season are way below the permissible value of $500 \mathrm{mg} / \mathrm{L}$ for Class AA and $1000 \mathrm{mg} / \mathrm{L}$ Class A. This implies that in terms of TDS the river water could be considered a potential source of drinking water requiring disinfection only because it passed the requirement of Class AA water as set in DAO 34 of 1990. This outcome implies that the watershed of the Aligodon River is healthy because the concentration of dissolved solids is found minimal.

Like TDS, the values of the DO in the river water of both seasons connote good quality because they surpass the permissible standard value of both Class AA and Class A water. The DO of $8.52 \mathrm{mg} / \mathrm{L}$ and $7.55 \mathrm{mg} / \mathrm{L}$ during wet season and dry season, respectively are higher than the permissible requirement of at least $5.0 \mathrm{mg} / \mathrm{L}$ for Class AA and Class A waters. 
Table 6. Comparison of the Physicochemical Characteristics of Aligodon River and the DENR Administrative Order 34 of 1990

\begin{tabular}{|c|c|c|c|c|c|}
\hline \multirow{2}{*}{ Parameter } & \multicolumn{2}{|c|}{$\begin{array}{c}\text { DAO } 34 \\
\text { Standard Value }\end{array}$} & \multicolumn{2}{|c|}{ Mean Value } & \multirow{2}{*}{ Remarks } \\
\hline & Class AA & Class A & $\begin{array}{c}\text { Wet } \\
\text { Season }\end{array}$ & $\begin{array}{c}\text { Dry } \\
\text { Season }\end{array}$ & \\
\hline Turbidity, NTU & - & - & 69.00 & 40.50 & - \\
\hline $\mathrm{TDS}, \mathrm{mg} / \mathrm{L}$ & $500^{(i)}$ & $1000^{(\mathrm{i})}$ & 86.00 & 32.25 & all Pass \\
\hline $\mathrm{DO}, \mathrm{mg} / \mathrm{L}$ & 5.0 & 5.0 & 8.52 & 7.55 & all Pass \\
\hline $\mathrm{pH}$ & $6.5-8.5$ & $6.5-8.5$ & 6.73 & 6.93 & all Pass \\
\hline Nitrates as Nitrogen, mg/L & 1.0 & 10.0 & 2.41 & 1.41 & both seasons pass Class A \\
\hline $\mathrm{BOD}, \mathrm{mg} / \mathrm{L}$ & 1.0 & 5.0 & $0.60 *$ & 1.24 & the dry season did not pass Class AA \\
\hline Total Coliform, & 50 & 1000 & $* *$ & $* *$ & - \\
\hline Temperature, ${ }^{\circ} \mathrm{C}$ & - & - & 19.50 & 22.63 & - \\
\hline Phosphates as Phosphorous, mg/L & nil & 0.1 & 0.34 & 0.003 & only dry season pass Class A \\
\hline
\end{tabular}

In terms of DO, Aligodon River water is good quality and a potential source for the potable water system. This result is supported by Hateley [14] stressing that higher concentration of DO means better water quality.

When it comes to $\mathrm{pH}$ of the river water, the result revealed that $\mathrm{pH}$ during the wet season of 6.73 and dry season of 6.93 are within the range of acceptable $\mathrm{pH}$ of $6.5-8.5$ as stipulated in DAO 34 both for Class AA and Class A waters. The result means that the observed $\mathrm{pH}$ during wet and dry seasons both passed the standard set value. This finding implies that minimal anthropogenic activities near the river did not significantly affect the $\mathrm{pH}$ of the water. In this level of $\mathrm{pH}$, the quality of river water is good in supporting aquatic life.

In terms of phosphates as phosphorous, Class AA and Class A waters have a standard value of nil and $0.1 \mathrm{mg} / \mathrm{L}$, respectively. The nil standard means phosphate as phosphorous is extremely in low concentration and not detectable by existing equipment. The result revealed that phosphate as a phosphorous content of both seasons has been detected thus it failed the permissible standard of Class AA water. On the other hand, comparing it to Class A with a permissible standard of $0.1 \mathrm{mg} / \mathrm{L}$, the result disclosed that only phosphates as phosphorous content observed during the dry season of $0.003 \mathrm{mg} / \mathrm{L}$ has passed the permissible standard value. But, the wet season phosphate as a phosphorous content of $0.34 \mathrm{mg} / \mathrm{L}$ is quite higher compared to the Class A permissible standard value of $0.1 \mathrm{mg} / \mathrm{L}$. Though phosphate as phosphorous content at this season did not pass DAO 34 for Class AA and Class A yet such concentration is too little to alter the river water quality. Further, concerning this parameter, the river water is acceptable for drinking having no standards set by PNSDW.

Regarding nitrates as nitrogen, it is observed that its concentration during the wet season of $2.41 \mathrm{mg} / \mathrm{L}$ and 1.41 $\mathrm{mg} / \mathrm{L}$ during the dry season did not pass the $1.0 \mathrm{mg} / \mathrm{L}$ allowable standard value to be considered as Class AA water. However, both values give the Class A classification because it is below $10 \mathrm{mg} / \mathrm{L}$ allowable standard. Though this nitrate content did not pass DAO 34 for Class AA water, the values during the two seasons still meet the PNSDW permissible value. This finding implied that the concentration of the nitrates as nitrogen in the river water is tolerable as far as the standard for drinking water as provided by PNSDW and could be considered as safe water for drinking.

There is no standard stipulated in DAO 34 for the temperature of Class AA. On the basis of Class A, the standard set three (3) units allowable temperature increase over the average ambient temperature for each month is acceptable. The study did not focus on a monthly basis. However, the result showed that the numerical difference between the two seasons of the year, where water temperature may reach extreme values, has a mean difference of 3.13. This finding indicates that change in the temperature of the water during the two seasons of the year is a little greater than the 3 units' allowable requirement of DAO 34 for Class AA water.

In terms of BOD, the result showed that the BOD during the wet season passed the permissible standard set by DAO 34 both for Class AA and Class A water. The $0.60 \mathrm{mg} / \mathrm{L}$ during the rainy season is better than the permissible level of 1.0 $\mathrm{mg} / \mathrm{L}$ and $5.0 \mathrm{mg} / \mathrm{L}$ for Class AA and Class A waters, respectively. Conversely, the BOD of the lower station of $1.24 \mathrm{mg} / \mathrm{L}$ did not pass the permissible value of $1.0 \mathrm{mg} / \mathrm{L}$ to be considered as Class AA water. The lower station only passed the allowable value of $5.0 \mathrm{mg} / \mathrm{L}$ for Class A water. This result connotes that the greater amount of DO concentration during wet season decreases the requirement of BOD. Besides, this implies that there is a minimal change in the organic loading into the river; thus, it did not increase the amount of BOD requirement.

In terms of total coliform, the result showed that there are TNTC values both at the upper and lower stations which 
lead to unquantified mean value. However, the TNTC values signals that the water is both contaminated starting from the upper station and is carried going to the lower station. The result highlights that coliform is present in the area. Though fecal coliform is the precise indicator of the presence of pathogens yet it is suggested that water treatment should be part of the design of the water system to ensure clean and safe drinking water.

\subsection{Aligodon River Water Characteristics during}

\section{Wet and Dry Seasons}

As shown in Table 7, the probability value of 3.01 x 10-5 signifies that there is strong evidence to prove that the river water temperature during the two seasons differs significantly. It indicates that the mean temperature during the dry season of $22.63{ }^{\circ} \mathrm{C}$ is significantly higher than the river water temperature during the wet season of $19.50{ }^{\circ} \mathrm{C}$. This outcome means that during the dry season the river water temperature is affected by the atmospheric temperature of the surroundings. When this river water is directly used for drinking, the user may find the water more appetizing during the wet season because of its coldness. Besides, cold water during the wet season when used for drinking would then be advantageous because it requires a little amount of energy to attain the most desirable coldness when refrigerated.

In terms of turbidity, the probability value of 0.07 indicates that there is no substantial evidence to prove that the turbidity of water changes when the season changes. This outcome means that turbidity mean value of 69 NTU during the wet season is not statistically different to the $40.50 \mathrm{NTU}$ during the dry season. This finding suggests that regardless of the season the clarity of water does not change considerably. One of the reasons is the land use of the watershed where a greater proportion is considered forest areas. Only naturally occurring activities with runoff contributed to the increase in turbidity during the wet season. The result implied that when this river water will be used for drinking, there is no significant change in the clarity of water in any season of the year

Table 7. Result of the t-Test Analysis Comparing River Water Characteristics during Wet and Dry Seasons

\begin{tabular}{lcccc}
\hline \multirow{2}{*}{ Parameters } & \multicolumn{2}{c}{ Mean Value } & p-value & Remarks \\
\cline { 2 - 3 } & Wet season & Dry season & & \\
\hline Temperature, ${ }^{\circ} \mathrm{C}$ & 19.50 & 22.63 & 0.00 & $*$ \\
Turbidity, NTU & 69.00 & 40.50 & 0.07 & $n s$ \\
Total Dissolved Solids, mg/L & 86.00 & 32.25 & 0.04 & $*$ \\
& 8.52 & 7.55 & 0.01 & $*$ \\
Dissolved Oxygen, mg/L & 6.73 & 6.93 & 0.11 & $n s$ \\
pH & 1.03 & 0.01 & 0.09 & $n s$ \\
Phosphates, mg/L & 10.67 & 6.25 & 0.00 & $*$ \\
Nitrates, mg/L & & & & \\
Biochemical Oxygen Demand, mg/L & 0.60 & 1.24 & 0.17 & $n s$
\end{tabular}

Total coliform,

TNTC TNTC

*-significantly different, ns -not significantly different, TNTC -means Too Numerous to Count that the water microorganisms is too crowded that cannot be counted anymore

It is discovered that there is substantial evidence to prove that the amount of TDS in the river water is significantly different during the two seasons through the probability value of 0.04 . This finding means that the TDS of $86 \mathrm{mg} / \mathrm{L}$ during the wet season is significantly higher than the TDS during the dry season of $32.25 \mathrm{mg} / \mathrm{L}$. This result indicates that the season of the year has an influence of TDS concentration present in the river water. The runoff water during rainy days that is received by the river water carries dissolved substances that added the TDS level. Though the concentration is tolerable based on PNSDW permissible value, the result conveys that there are dissolved substances that intruded into the water from the Aligodon watershed during the wet season.

Based on the statistical analysis comparing the DO concentration of the river water during wet and dry seasons, the p-value of 0.01 connotes significant difference of the means. This outcome indicates that there is substantial proof to conclude that the concentration of DO of $8.52 \mathrm{mg} / \mathrm{L}$ during the wet season is significantly higher than $7.55 \mathrm{mg} / \mathrm{L}$ during the dry season. This result implies that the discharge is high during the rainy season, and there is a tendency that the water is much turbulent thereby increasing the DO. It may also be attributed to a low temperature of river water during wet season that made it more capable of holding oxygen. This is supported by Hateley [14] stressing that the ability of water to hold oxygen is inversely proportional to the temperature of water.

The result in $\mathrm{pH}$ which printed a p-value of 0.11 , leads to the conclusion that there is sufficient evidence to show that the $\mathrm{pH}$ of the river water during the wet and dry season is not significantly different. This means that the $\mathrm{pH}$ of 6.73 during the wet season is statistically not different to the $\mathrm{pH}$ of 6.93 during the dry season. This result disproves the claim of Hateley [14] stressing that $\mathrm{pH}$ can naturally change daily and or seasonally. The result implies that the river 
water $\mathrm{pH}$ is not affected by the season of the year. Its value is within the acceptable range of 6.5-85 as set by PNSDW and can be considered as a good source of drinking water. This river water, almost near to neutral value of 7 , can be consumed without adverse health effects [13].

In terms of the concentration of phosphates, the analysis revealed a $\mathrm{p}$-value of 0.09 . This means that there is no evidence of the differences in the phosphates concentration during the wet or dry season. The result connotes that the concentration of phosphates of $1.03 \mathrm{mg} / \mathrm{L}$ during the wet season is not significantly different to $0.01 \mathrm{mg} / \mathrm{L}$ during the dry season.

Contrary to phosphates, the nitrates concentration analysis discloses a p-value of $8.20 \times 10-4$. This indicates that there is sufficient evidence to prove that the nitrates concentration of $10.67 \mathrm{mg} / \mathrm{L}$ during the wet season is significantly higher than $6.25 \mathrm{mg} / \mathrm{L}$ during the dry season. Though these are within the permissible values set by PNSDW, the result implies that during the wet season the nitrates-containing materials are incorporated into the water body of Aligodon River. This may be through run-off water that carries nitrates compound from the decomposing organic matters and the fertilizers from the small scale farming in the watershed.
The result of BOD testing of the Aligodon River water in comparing wet and dry seasons revealed a p-value of 0.17 . This finding discloses that there is no enough evidence to prove that the values of BOD during wet and dry seasons are significantly different. This result means that the season did not affect the amount of BOD requirement of the Aligodon River water to decompose naturally occurring organics in the water.

The coliform level could not be analyzed because of the TNTC values that could not be quantified. High caliber equipment is needed in order to quantify those microorganisms. On the lighter side, the TNTC value signifies that coliform treatment is one of the considerations in the design of the water system.

\subsection{Aligodon River Water Characteristics at the Upper and the Lower Stations}

Table 8 shows that the $\mathrm{P}$ values of the parameters tested are all greater than 0.05 . These values connote that there is no evidence of the differences in the parameters tested the river water of Aligodon at the upper and the lower stations.

Table 8. Result of the t-Test Analysis Comparing River Water Characteristics at the Upper and the Lower Stations

\begin{tabular}{lcccc}
\hline \multirow{2}{*}{ Parameters } & \multicolumn{3}{c}{ Mean Value } & \multirow{2}{*}{ p-value Remarks } \\
\cline { 2 - 3 } & Upper Station & Lower Station & & \\
\hline Temperature, ${ }^{\circ} \mathrm{C}$ & 20.75 & 21.38 & 0.32 & $n s$ \\
Turbidity, NTU & 40.50 & 69.00 & 0.07 & $n s$ \\
Total Dissolved Solids, mg/L & 59.38 & 58.88 & 0.50 & $n s$ \\
Dissolved Oxygen, mg/L & 8.00 & 8.08 & 0.44 & $n s$ \\
$\mathrm{pH}$ & 6.78 & 6.88 & 0.27 & $n s$ \\
Phosphates, mg/L & 0.35 & 0.70 & 0.31 & $n s$ \\
Nitrates, mg/L & 8.24 & 8.68 & 0.41 & $n s$ \\
Biochemical Oxygen Demand, mg/L & 1.17 & 0.68 & 0.23 & $n s$ \\
Total Coliform & $* *$ & $* *$ & - & - \\
\hline
\end{tabular}

ns-not significant, ${ }^{* *}$ with TNTC values. The TNTC value means Too Numerous to Count that the water microorganisms is too crowded that cannot be counted anymore

The results imply that the quality of the river water at the upper station does not significantly change when it reached to the lower station. Though it can be generally observed that the numerical mean values increase at the lower station, the changes do not significantly alter the water quality. In term of total coliform, the result could not be tested due to the TNTC values that could not be quantified.

\section{CONCLUSIONS}

Based on the permissible standards set by PNSDW and DAO 34, the Aligodon River water passed the TDS, DO, $\mathrm{pH}$, nitrates, BOD parameters. Only turbidity and total coliform failed the set standards. High turbidity of the river water, especially during wet seasons, requires filtration to remove foreign materials that may serve as the hiding place of microorganisms during disinfection. The presence of the total coliform does not necessarily indicate that river water is unsafe, however, treatment, namely; microfiltration followed by disinfection is needed before the water will be brought to the end pipe for consumption. Further, an analysis of $E$. coli, the confirmatory indicator of the presence of fecal contamination and pathogens is needed to validate the total coliform analysis. Meanwhile, there is a minimal amount of phosphorous dissolved in water however no standard is set in the PNSDW. The level of water quality of Aligodon River is recommended for the new Claveria Water System. Specifically, river water can be used for drinking after undergoing treatment processes such as rapid screening and filtration, microfiltration and disinfection/chlorination.

\section{ACKNOWLEDGMENT}

The author would like to acknowledge the financial support of the Faculty Development Program of the Philippine Commission on Higher Education (CHED) and the technical help of Engr. Ma. Isabel Dumlao and Dr. Renato O. Arazo. 


\section{REFERENCES}

[1] Lenton, Roberto. Water and Sanitation. Health, Dignity and Development: What Will it Take? Millennium Project. Earthscan. 2005.

[2] Alikpala, R. "Philippine Country Water Highlights". National Water Resources Board. December 2006.

[3] Situational Analysis of the Municipality of Claveria.2009

[4] Kiely, Gerardo. Environmental Engineering. International Edition. Singapore: Mc Graw Hill Book Companies, 1998.

[5] Environment Australia. Waterwatch Australia Steering Committee. Retrieved February 27, 2010 from http://www.hort.wisc.edu/cran/pubs archive/newsletters/2003/news 200307 05.html.

[6] Philippines National Standards for Drinking Water. Local Water Utilities Administration. Philippines

[7] DENR Administrative Order (DAO) 34. Department of Environment and Natural Resources in the Philippines.1990

[8] Water-Research. Retrieved January 12, 2010, from http://www.water-research.net/nitrite.htm (no date)

[9] Environment Australia. Waterwatch Australia Steering Committee. Retrieved February 27, 2010 from http://www.hort.wisc.edu/cran/pubs archive/newsletters/2003/news 200307 05.html (2002)

[10] US Department of the Interior. Total Coliform and Ecoli Fact Sheet. Retrieved January 13, 2010 from http://www.usbr.gov/pmts/water/ media/pdfs/TC\&Ecoli.pd.

[11] Washtenaw Country Michigan. Environmental Health Fact Sheet- Coliform Bacteria and Drinking Water. Retrieved January 13, 2010 from www.ewashtenaw.org/.../environmental health/.../eh_coliformfactsheet.pdf. (1998)

[12] Tchobanoglous, George and Franklin Burton. Wastewater Engineering: Treatment, Disposal, and Reuse. Metcalf \& Eddy, Inc. 3rd edition. Mcgraw-Hill, Incorporated. 1991

[13] Nathanson, Jerry A. Basic Environmental Technology. Water Supply, Waste Management and Pollution Control. Second Edition. New Jersey: Prentice Hall Inc., 1997.

[14] Hately, Louise. Community Water Quality Monitoring Manual. 2006.

\section{BIOGRAPHY}

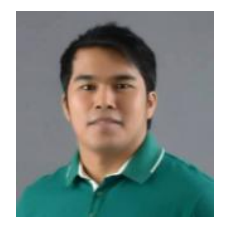

Engr Alexander L. Ido is an Assistant Professor of the Institute of Engineering and Technology of MOSCAT. He was a visiting scholar at Texas A\&M University, Texas, USA. 